\title{
UDC 615.2:658.8:005.52]:618.19-006.6-085](477)
}

https://doi.org/10.32345/USMYJ.4(127).2021.77-83

Received: September 16,2021

Accepted: November 21,2021

\section{MARKETING RESEARCH OF THE MEDICINE MARKET FOR THE TREATMENT OF BREAST CANCER IN UKRAINE}

\author{
Rafalska Yaroslava ${ }^{1}$, Kosyachenko Kostyantin ${ }^{2}$ \\ ${ }^{1}$ Assistant of the Department of Economy and Organization of Pharmacy, Bogomolets National Medical \\ University, Ukraine \\ ${ }^{2}$ Doctor of Pharmacy, Professor, Head of the Department of Organization and Economy of Pharmacy, \\ Bogomolets National Medical University, Ukraine
}

\begin{abstract}
: the article presents the results of the study of the marketing market of medicines for the treatment of breast cancer in Ukraine during 2019-2020. Medicine treatment schemes based on a clinical protocol were analyzed. On December 1, 2019, 184 drugs were registered for the treatment of breast cancer in Ukraine, and on December 1, 2020 - 194. In 2020, the largest share among of the studied drugs belongs to the group of antineoplastic and immunomodulatory drugs $-82.0 \%$, and the group of drugs that affect the musculoskeletal system - $18.0 \%$. On December 1, 2020, drugs were represented by 43 manufacturers, of which $18.6 \%$ were Ukrainian and $81.4 \%$ were foreign. Among Ukrainian companies, the primacy belongs to Pharmex Group LLC (4.1\%), Teva Ukraine LLC (3.1 $\%)$ and Farmak JSC (2.6\%). The largest share of foreign suppliers occupies Great Britain - 26.3\%, Switzerland and India by $11.9 \%$. At that time, in 5 pharmacotherapeutic groups (L01AA01, L01BA01, L01CA04, L01XC07, M05BA03) is not represented by any drug Ukrainian manufacturer. Analysis of the assortment of drugs for the treatment of breast cancer by dosage form in 2020 showed that the main share (35.6\%) is represented by concentrate for solution for infusion, $21.6 \%$ - tablets and $20.6 \%$ - lyophilisate for solution for infusion. Other dosage forms form a total of $22.2 \%$ of the total assortment of drugs, studied in the Ukrainian market.
\end{abstract}

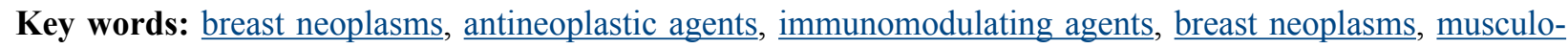
skeletal system.

Introduction. One of the most important medical and social problems in Ukraine and the world is the spread of malignant neoplasms (MN). Today, the incidence and mortality of the population from malignant neoplasms tend to rapid growth due to internal (age, sex, race, heredity) and external factors (lifestyle, eating habits, long-term medical intervention, such as the use of oral hormonal contraceptives or hormone replacement therapy) (Kamińska, Ciszewski, Łopacka-Szatan, Miotła, Starosławska, 2015). According to the World Health Organization, breast cancer (BC) ranks second in the world among all diseases as one of the most common, after lung cancer. In Ukraine, among the female population of breast cancer ranks first in the structure of cancer morbidity and mortality (WHO. International Agency for Research on Cancer). In connection with the above, the pharmaceutical supply of this group of patients, due to the necessary high-cost treatment, requires the involvement of significant financial resources for chemotherapy.

Since 2015, the Ministry of Health of Ukraine to ensure the effectiveness of treatment of cancer patients and improve their quality of life began to purchase drugs and medical devices in the field - chemotherapeutic drugs, radiopharmaceuticals and accompanying drugs for the treatment of cancer patients through such international organizations such as the United Nations Development Program, the UNICEF Children's Fund and the British purchasing agency Crown Agents.

Scientists from different countries deal with the organization of providing the population with drugs for the treatment of breast cancer. Clinical and economic analysis of drugs for the treatment of breast cancer was conducted by Ukrainian scientists Nemchenko A.S., Podgaina M.V. (Nemchenko, Podgaynaya, 2009). The study of valuation was carried out by Berghuis A., Koffijberg H. and others (Berghuis, Koffijberg, Terstappen, Sleijfer, IJzerman, 2018).

The aim of the work was to study the saturation of the market with assortment positions and physical accessibility for patients of drugs for the treatment of breast cancer in the pharmaceutical market of Ukraine.

Materials: In 2015, the Ministry of Health of Ukraine developed and approved a unified clinical protocol for 
primary, secondary (specialized), tertiary (highly specialized) medical care "Breast Cancer" (further - the Clinical Protocol for Breast Cancer) (Order of the Ministry of Health of Ukraine). It is based on the clinical guideline "SIGN Guideline 84: Breast Cancer in Women", which was proposed by the national health service "Scottish Intercollegiate Guidelines Network (SIGN)", and some sections are based on other guidelines, in particular:

NICE Clinical Guideline update CG 041: Familial breast cancer: the classification and care of women at risk of familial breast cancer in primary, secondary and tertiary care (partial update of CG 14), 2006 (Great Britain) (National Collaborating Centre for Primary Care, 2006).

NICE clinical guideline 164 Classification and care of people at risk of familial breast cancer and management of breast cancer and related risks in people with a family history of breast cancer, 2013 (Great Britain) (National Institute for Health and Care Excellence, 2013).

Advanced breast cancer. Diagnosis and treatment. National Collaborating Centre for Cancer. Feb 01, 2009 (Great Britain) (National Collaborating Centre for Cancer, 2009a).

Early and locally advanced breast cancer. Diagnosis and treatment. National Collaborating Centre for Cancer. Feb 01, 2009 (Great Britain) (National Collaborating Centre for Cancer, 2009b).

ESMO Clinical Practice Guidelines for diagnosis, treatment and follow-up Primary breast cancer, August 2013 (Senkus, Kyriakides, Ohno, Penault-Llorca, Poortmans, Rutgers, Cardoso, 2015).

ESO - ESMO 2nd international consensus guidelines for advanced breast cancer (ABC2), September 2014 (Cardoso, Costa, Norton, Senkus, Aapro, Andre, Winer, 2014).

In the above-mentioned Clinical Protocol for breast cancer presents the schemes of drug treatment of breast cancer (chemotherapy, hormone therapy) and two lists (main and additional) of drugs used. An additional list of drugs is used when the relevant health care facility has sufficient funding, including the expense of the local budget, which in turn leads to improved quality and accessibility of treatment for citizens (Order of the Ministry of Health of Ukraine).

In the future, to implement the objectives of the study, a marketing analysis of the range of drugs used in the medical treatment of breast cancer. According to the unified anatomical-therapeutic and chemical classification system (ATC), the studied drugs belong to the groups "L - antineoplastic and immunomodulatory agents" and "M - agents that affect the musculoskeletal system". The subgroup of L-drugs includes L01 - antineoplastic drugs (L01A - alkylating compounds, L01B - antimetabolites, L01C - alkaloids of plant origin and other drugs of natural origin, L01D - cytotoxic antibiotics and related drugs and L01X - other antineoplastic drugs). The group of
M-drugs is represented by the subgroup M05 - drugs used to treat bone diseases (M05B - agents that affect the structure and mineralization of bones).

Among the above groups of drugs was formed a sample containing 15 names of drugs under international non-proprietary names and ATC codes, such as Cyclophosphamide (L01AA01), Methotrexate (L01BA01), Fluorouracil (L01BC02), Doxorubicin (L01D11) (L01CD02), Capecitabine (L01BC06), Gemcitabine (L01BC05), Vinorelbine (L01CA04), Trastuzumab (L01XC03), Bevacizumab (L01XC07), Zoledronic acid (M05BA08), Pamidronic acid (M05BA03), Ironic acid M05BA02).

To study the saturation of the market of drugs for the treatment of breast cancer, the State Register of Medicines of Ukraine was analyzed, which is presented on the official website of the State Expert Center of the Ministry of Health of Ukraine, data of the specialized medical internet-edition "Compendium 2019 - drugs" and scientific and practical publications on the topic of the article.

Methods. The methods of market research, systematization and generalization of the obtained results were used in the work.

Discussion. The study was conducted during 20192020 years. On December 1, 2019, 184 drugs were registered for the treatment of breast cancer in Ukraine, and on December 1, 2020 - 194 drugs.

At the first stage of the study, the results of the distribution of registered drugs by groups of ATC were analyzed. In 2020, the largest share among the studied drugs belongs to the group of antineoplastic and immunomodulatory drugs $-82,0 \%$ (159 drugs), and the group of drugs that affect the musculoskeletal system - 18,0\% (35 drugs). All registered drugs on the pharmaceutical market of Ukraine are mono-drugs. A similar trend was proved by us in the market research in 2019 (Table 1).

The next stage was the study of the range of domestic and imported drugs for the treatment of breast cancer in the pharmaceutical market of Ukraine. According to the results of the analysis, it was found that the majority of registered drugs for the treatment of breast cancer in 2019-2020 years are drugs of foreign origin (Table 2). On December 1, 2020, drugs were represented by 43 manufacturing companies, of which $8(18,6 \%)$ were pharmaceutical companies - Ukrainian, and foreign - 35 (81,4\%). Among Ukrainian companies, the first place belongs to Pharmex Group LLC (8 drugs, 4,1 \%). The second and third places are occupied by Teva Ukraine LLC (6 drugs, 3,1 \%) and Farmak JSC (5 drugs, 2,6 \%), respectively. The next place belongs to 02 Pharma LLC ( 2 drugs, 1,0 $\%)$. The other four Ukrainian manufacturers, such as Lumier Pharma LLC, Rocket-Pharm LLC, Lekhim-Kharkiv JSC and Sanofi-Aventis Ukraine LLC, supply only one drug to the Ukrainian market. Compared to 2019, the number of Ukrainian pharmaceutical manufacturers has 


\begin{tabular}{|c|c|c|c|c|c|}
\hline \multirow{2}{*}{ Group code } & \multirow{2}{*}{$\begin{array}{c}\text { Pharmacotherapeutic } \\
\text { group }\end{array}$} & $\begin{array}{c}\text { Number of } \\
\text { drugs }\end{array}$ & $\begin{array}{c}\text { Specific weight } \\
\text { (\%) }\end{array}$ & $\begin{array}{c}\text { Number of } \\
\text { drugs }\end{array}$ & $\begin{array}{c}\text { Specific } \\
\text { weight (\%) }\end{array}$ \\
\cline { 3 - 6 } & & \multicolumn{2}{|c|}{2019} & \multicolumn{2}{|c|}{2020} \\
\hline L01AA01 & Cyclophosphamide & 5 & 2,7 & 5 & 2,6 \\
\hline L01BA01 & Methotrexate & 15 & 8,2 & 16 & 8,2 \\
\hline L01BC02 & Fluorouracil & 6 & 3,3 & 7 & 3,6 \\
\hline L01DB01 & Doxorubicin & 9 & 4,9 & 14 & 7,2 \\
\hline L01CD01 & Paclitaxel & 17 & 9 & 19 & 9,8 \\
\hline L01CD02 & Docetaxel & 15 & 8,2 & 14 & 7,2 \\
\hline L01BC06 & Capecitabine & 27 & 14,7 & 29 & 15,0 \\
\hline L01BC05 & Gemcitabine & 32 & 17,4 & 31 & 16,0 \\
\hline L01CA04 & Vinorelbine & 5 & 2,7 & 4 & 2,1 \\
\hline L01XC03 & Trastuzumab & 10 & 5,4 & 17 & 8,8 \\
\hline L01XC07 & Bevacizumab & 1 & 0,5 & 3 & 1,5 \\
\hline M05BA08 & Zoledronic acid & 27 & 14,7 & 21 & 10,8 \\
\hline M05BA03 & Pamidronic acid & 2 & 1 & 2 & 1,0 \\
\hline M05BA06 & Ibandronic acid & 12 & 6,5 & 12 & 6,2 \\
\hline M05BA02 & Clodronic acid & 1 & 0,5 & 0 & 0,0 \\
\hline & Total: & $\mathbf{1 8 4}$ & $\mathbf{1 0 0}$ & $\mathbf{1 9 4}$ & $\mathbf{1 0 0}$ \\
\hline
\end{tabular}

Table 1. Distribution of drugs registered in Ukraine by groups of ATC classification used for the treatment of breast cancer

increased by one, and the number of manufacturers supplying the Ukrainian market - second place, among all the countries represented in 2019-2020 years.
The largest share among foreign suppliers in 2020 is occupied by such countries as the Great Britain - 51 drugs $(26,3 \%)$, Switzerland - 23 drugs $(11,9 \%)$ and In-

Fig. 1. The structure of the range of drugs for the treatment of breast cancer (on 01.12.2020)

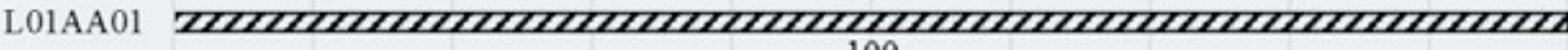

L01BA01 100 (1)

L01BC02 00000000000000000000000000000000000000000114,3

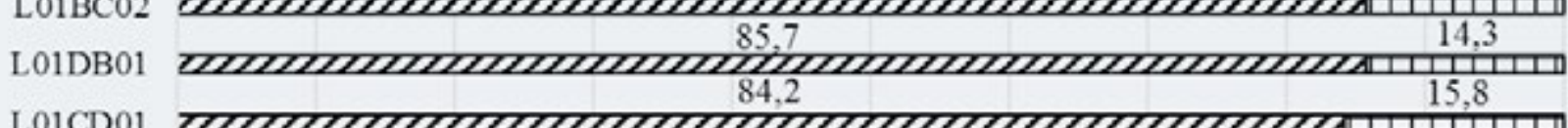

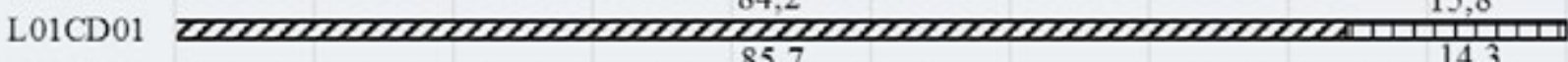

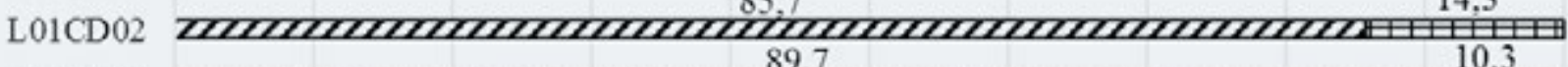

L01BC06 20000m $\frac{89,7}{10,3}$

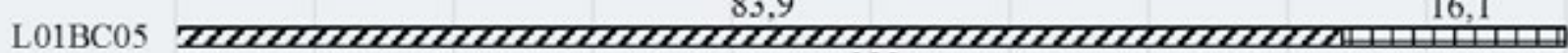

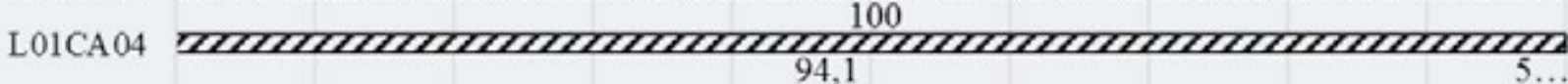

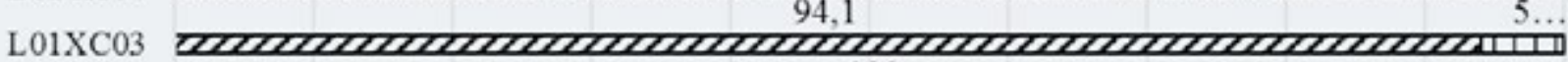

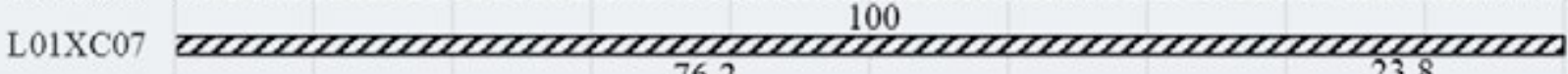

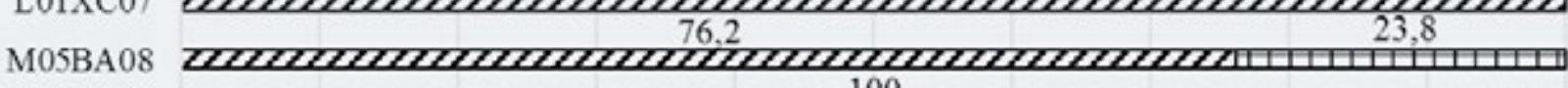

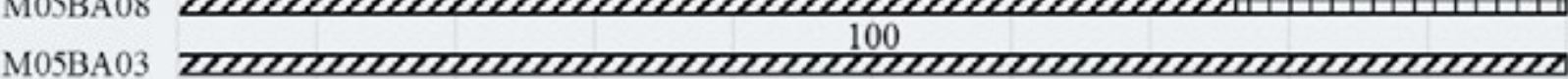

M05BA06 zmm

a Foreign manufacturers (\%) QUkrainian manufacturers (\%) 


\begin{tabular}{|c|c|c|c|c|}
\hline № & Country & Manufacturer & Number of drugs & $\begin{array}{c}\text { The ratio of \% to } \\
\text { total }\end{array}$ \\
\hline 1 & \multirow{5}{*}{ Great Britain } & Mistral Capital Management Ltd. & 18 & \multirow{5}{*}{26,3} \\
\hline 2 & & Accord Healthcare Ltd. & 11 & \\
\hline 3 & & Amaxa Pharma Ltd. & 10 & \\
\hline 4 & & M. Biotech Ltd. & 10 & \\
\hline 5 & & Ananta Medicare Ltd. & 2 & \\
\hline 6 & \multirow{8}{*}{ Ukraine } & Pharmex Group LLC & 8 & \multirow{8}{*}{12,4} \\
\hline 7 & & Teva Ukraine LLC & 6 & \\
\hline 8 & & Farmak JSC & 4 & \\
\hline 9 & & 02 Pharma LLC & 2 & \\
\hline 10 & & Lekhim-Kharkiv JSC & 1 & \\
\hline 11 & & Lumier Pharma LLC & 1 & \\
\hline 12 & & Rocket-Pharm LLC & 1 & \\
\hline 14 & & Sanofi-Aventis Ukraine LLC & 1 & \\
\hline 15 & \multirow{4}{*}{ Switzerland } & F. Hoffmann-La Roche Ltd & 16 & \multirow{4}{*}{11,9} \\
\hline 16 & & Almeda Pharmaceuticals AG & 3 & \\
\hline 17 & & Accord Healthcare AG & 2 & \\
\hline 18 & & Novartis Pharma $\mathrm{A} \Gamma$ & 2 & \\
\hline 19 & \multirow{7}{*}{ India } & Hetero Labs Limited & 9 & \multirow{7}{*}{11,9} \\
\hline 20 & & Dr. Reddy's Laboratories Ltd & 6 & \\
\hline 21 & & Glenmark Pharmaceuticals Ltd & 2 & \\
\hline 22 & & RR Pharmaceuticals Private Limited & 2 & \\
\hline 23 & & Shilpa Medicare Limited & 2 & \\
\hline 24 & & Emcure Pharmaceuticals Ltd & 1 & \\
\hline 25 & & Sun Pharmaceutical Industries Ltd & 1 & \\
\hline 26 & \multirow{4}{*}{ Germany } & Medak Gezelshaft Ffyur Kklinishe SHP & 13 & \multirow{4}{*}{10,3} \\
\hline 27 & & Baxter Oncology GmbH & 4 & \\
\hline 28 & & Fresenius Kabi Deutschland GmbH & 2 & \\
\hline 29 & & Denk Pharma GmbH \& Co. KG & 1 & \\
\hline 30 & Austria & Ebewe Pharma, GmbH Nfg KG & 14 & 7,2 \\
\hline 31 & USA & Pfizer Inc & 7 & 3,6 \\
\hline 32 & Republic of Belarus & Belmedpreparaty RUE & 5 & 2,6 \\
\hline 33 & Israel & Teva Pharmaceutical Industries Ltd & 4 & 2,1 \\
\hline 34 & Cyprus & M-Invest Ltd & 4 & 2,1 \\
\hline 35 & \multirow{2}{*}{ Slovenia } & KRKA, d.d., Novo mesto & 3 & \multirow{2}{*}{2,1} \\
\hline 36 & & Sandoz Pharmaceuticals d.d. & 1 & \\
\hline 37 & Spain & Accord Healthcare, S.L.U. & 3 & 1,5 \\
\hline 38 & Finland & Orion Corporation & 2 & 1,0 \\
\hline 39 & France & Mylan, SAS & 2 & 1,0 \\
\hline 40 & Canada & Pharmascience Inc. & 2 & 1,0 \\
\hline 41 & Netherlands & Samsung Bioepis NL B.V. & 2 & 1,0 \\
\hline 42 & Republic of Korea & Celltrion Healthcare Co., Ltd & 2 & 1,0 \\
\hline 43 & Poland & Green Life Sciences LLC & 1 & 0,5 \\
\hline 44 & Georgia & Rompharm Company Georgia LLC & 1 & 0,5 \\
\hline \multicolumn{3}{|c|}{ Total: } & 194 & 100 \\
\hline
\end{tabular}




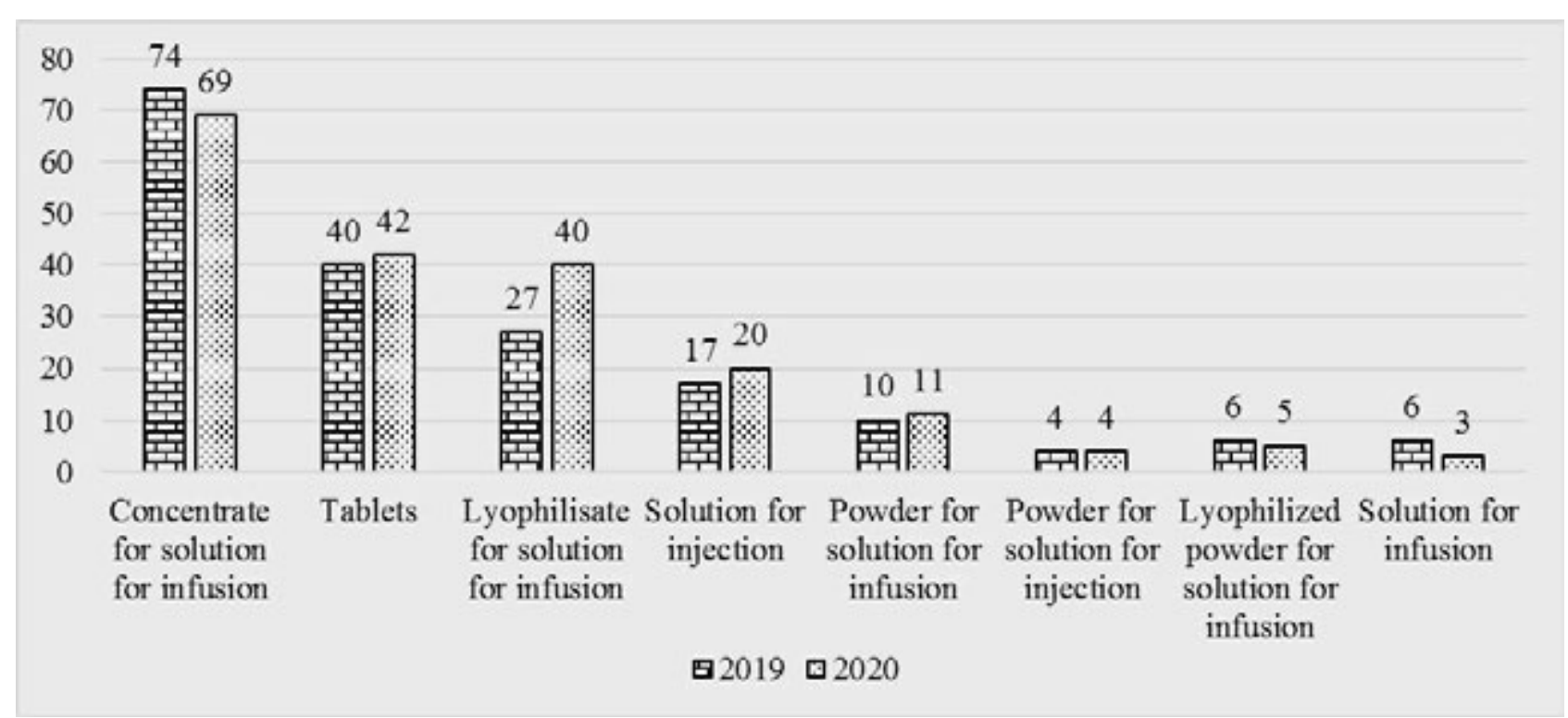

Fig. 2. Distribution of drugs for the treatment of breast cancer by dosage forms

dia - 23 drugs (11,9 \%). Compared to 2019, Germany came out of the top three, and its place was taken by India. In 2019-2020 years, the largest number of drugs from the Great Britain will be supplied by Mistral Capital Management Ltd. - 18 drugs (9,3\%), from Switzerland - F. Hoffmann-La Roche Ltd. (16 drugs, 8,2 \%) and India - Hetero Labs Limited (9 drugs, 4,6 \%).

According to the results of the analysis of the structure of pharmacotherapeutic groups of drugs by manufacturer-countries, it was found that among Ukrainian drugs the largest share is occupied by groups M05BA08 (Zoledronic acid) - 5 drugs $(23,8 \%)$ and L01BC05 (Gemcitabine) - 5 drugs $(23,8 \%)$. At the same time 5 pharmacotherapeutic groups (L01AA01, L01BA01, L01CA04, L01XC07, M05BA03) not presented any drug from the Ukrainian manufacturer (Fig. 1). Also in 2020 , no registered drugs were presented in the group M05BA02 (Clodronic acid). One drug from the group M05BA02 was present in the clinical treatment protocol in 2019, but lost registration on the market.

Analysis of the range of drugs for the treatment of breast cancer by dosage form in 2020 year showed that the main share $(35,6 \%)$ is represented by concentrate for solution for infusion, 21,6\% - tablets and 20,6\% - lyophilisate for solution for infusion. Other dosage forms, such as powder for solution for injection, solution for injection, solution for infusion, powder for solution for infusion and lyophilized powder for solution for infusion, form a total of $22,2 \%$ of the total range of drugs, studied in the market of Ukraine (Fig. 2).

Comparing the indicators of registered dosage forms in 2019 year with 2020 year, the leadership remained in such dosage forms as concentrate for solution for infusion, tablets and lyophilisate for solution for infusion. This indicates that the preferences of doctors for the use of certain dosage forms in practice have not changed significantly, and the number of registered drugs has increased in proportion to them in the pharmaceutical market of Ukraine.

Conclusion. A study of the range of drugs for the treatment of breast cancer, which are registered in the pharmaceutical market of Ukraine in 2019-2020 years. According to the results of the study, it is established that antineoplastic and immunomodulatory drugs are the most widely represented on the Ukrainian market $-82,0 \%$ (159 drugs).

It is established that on December 1, 2020, domestic pharmaceutical manufacturers supplied to the market only $12,4 \%$ (24 drugs) of the total range of drugs for the treatment of breast cancer. Their production is carried out by 8 enterprises, among them the leaders in Ukraine are Pharmex Group LLC, Teva Ukraine LLC and Farmak JSC.

Most drugs for the treatment of breast cancer in Ukraine are drugs foreign countries such as Great Britain $-26.3 \%$, Switzerland $-11.9 \%$ and India - $11.9 \%$.

The analysis of the dosage forms of the study group showed that the main part $(35,6 \%)$ is a concentrate for solution for infusion, 21,6 \% - tablets and 20,6 \% - lyophilisate for solution for infusion, $22,2 \%$ - all other dosage forms.

Analysis of the range of drugs for the treatment of breast cancer in the Ukrainian market by the structure of manufacturers according to the ATX system showed that in 6 pharmacotherapeutic groups (L01AA01, L01BA01, L01CA04, L01XC07, M05BA03, M05BA02) no drug from the Ukrainian manufacturer. And in group M05BA02 (Clodronic acid) there are no registered drugs from manufacturers.

Conflict of interest: none.

Funding - this article did not receive external funding. 
Author contributions: research R.Y., substantiation of the purpose R.Y., analysis and generalization of results R.Y. and K.K., preparation of article R.Y. and K.K.
Consent to publication. All authors have read and approved the final version of the manuscript. All authors have agreed to publish this manuscript.

\section{References}

Berghuis, A. M. S., Koffijberg, H., Terstappen, L. W. M. M., Sleijfer, S., \& IJzerman, M. J. (2018). Evidence on the cost of breast cancer drugs is required for rational decision making. ecancermedicalscience, 12.

Cardoso, F., Costa, A., Norton, L., Senkus, E., Aapro, M., Andre, F., ... \& Winer, E. (2014). ESO-ESMO 2nd international consensus guidelines for advanced breast cancer (ABC2). The Breast, 23(5), 489-502.

Kamińska, M., Ciszewski, T., Łopacka-Szatan, K., Miotła, P., \& Starosławska, E. (2015). Breast cancer risk factors. Przeglad menopauzalny= Menopause review, 14(3), 196.

National Collaborating Centre for Cancer (UK. (2009). Advanced breast cancer: diagnosis and treatment.

National Collaborating Centre for Cancer (UK). (2009). Early and Locally Advanced Breast Cancer: Diagnosis and Treatment. National Collaborating Centre for Cancer (UK).

National Collaborating Centre for Primary Care (UK). (2006). Familial Breast Cancer: The Classification and Care of Women at Risk of Familial Breast Cancer in Primary, Secondary and Tertiary Care: Update. Royal College of General Practitioners (UK).

National Institute for Health and Care Excellence. Familial breast cancer: classification and care of people at risk of familial breast cancer and management of breast cancer and related risks in people with a family history of breast cancer. (Clinical guideline 164.) $\underline{2013 .}$

Nemchenko, A. S. (2009). Clinicaland economical analysis of pharmaceutical providing of the patients with breast cancer/Nemchenko AS, Podgaynaya MV. Вісник фармації, (1), 50-53.

Order of the Ministry of Health of Ukraine dated 30.06.2015 №396 "On approval and implementation of medical and technological documents for the standardization of medical care for breast cancer"

Senkus, E., Kyriakides, S., Ohno, S., Penault-Llorca, F., Poortmans, P., Rutgers, E., ... \& Cardoso, F. (2015). Primary breast cancer: ESMO Clinical Practice Guidelines for diagnosis, treatment and follow-up. Annals of oncology, 26, v8-v30.

World Health Organization. International Agency for Research on Cancer 


\section{МАРКЕТИНГОВІ ДОСЛІДЖЕННЯ РИНКУ ЛІКАРСЬКИХ ЗАСОБІВ ДЛЯ ЛІКУВАННЯ РАКУ МОЛОЧНОЇ ЗАЛОЗИ В УКРАЇНІ}

\section{Рафальська Ярослава ${ }^{1}$, Косяченко Костянтин}

${ }^{1}$ Асистент кафедри організації та економіки фармації Національного медичного університету імені О.О. Богомольця, м. Київ, Україна

2 Завідувач кафедри організації та економіки фармації Національного медичного університету імені О.О. Богомольця, м. Київ, Україна

Анотація: в статті представлено результати дослідження маркетингового ринку лікарських засобів для лікування раку молочної залози (РМ3) в Україні протягом 2019- 2020 років. Були проаналізовані схеми медикаментозного лікування РМЗ на основі клінічного протоколу. Станом на 01.12.2019 р. для лікування РМЗ в Україні було зареєстровано 184 ЛЗ, а на 01.12.2020 р. - вже 194. У 2020 році найбільша питома вага серед ЛЗ, що досліджувалися, належить групі антинеопластичних та імуномоделюючих засобів - 82,0\%, а групі засобів, що впливають на опорно-руховий апарат - 18,0\%. Станом на 01.12.2020p. Л3 представлені 43 фірмами-виробниками, 3 них $18,6 \%$ - українські, 81,4\% - іноземні. Серед українських фірм першість належить «Фармекс груп» $(4,1 \%)$, «Тева-Україна» $(3,1 \%)$ та «Фармак» $(2,6 \%)$. Найбільшу питому вагу серед іноземних постачальників займають Велика Британія - 26,3\%, Швейцарія та Індія по 11,9\%. Значну кількість ЛЗ із Великої Британії постачає фірма-виробник «Містрал Кепітал Менеджмент Лімітед» - 9,3\%, зі Швейцарії- «Ф. Хоформанн-Ля Рош Лтд» 8,2\% та Індії - «Гетеро Лабз Лімітед» $-4,6 \%$. У той час в 5 фармакотерапевтичних групах (L01AA01, L01BA01, L01CA04, L01XC07, M05ВА03) не представлено жодного препарату від українського виробника. Аналіз асортименту ЛЗ для лікування РМЗ за лікарськими формами у 2020 році показав, що основна їх частка $(35,6 \%)$ представлена концентратом для розчину для інфузій, $21,6 \%$ - таблетками та 20,6\% - ліофілізатом для розчину для інфузій. Інші лікарські форми, такі як порошок для розчину для ін'єкцій, розчин для ін'єкцій, розчин для інфузій, порошок для приготування розчину для інфузій та порошок ліофілізований для розчину для інфузій, складають сукупно 22,2\% від загального асортименту групи ЛЗ, що вивчається, на ринку України.

Ключові слова: новоутворення молочної залози, протипухлинні засоби, імуномодулюючі засоби, новоутворення молочної залози, кістково-м'язова система.

\section{МАРКЕТИНГОВЫЕ ИСЛЕДОВАНИЯ РИНКА ЛЕКАРСТВЕННЫХ СРЕДСТВ ДЛЯ ЛЕЧЕНИЯ РАКА МОЛОЧНОЙ ЖЕЛЕЗЫ В УКРАИНЕ}

\author{
Рафальская Ярослава ${ }^{1}$, Косяченко Константин ${ }^{2}$ \\ ${ }^{1}$ Ассистент кафедры организации и экономики \\ фармации Национального медицинского \\ университета имени А.А. Богомольца, г. Киев, \\ Украина \\ 2 Заведующий кафедры организации и экономики \\ фармации Национального медицинского \\ университета имени А.А. Богомольца, г. Киев, \\ Украина
}

Аннотация. в статье представлены результаты исследования маркетингового рынка лекарственных средств (ЛС) для лечения рака молочной железы (РМЖ) в Украине в 2019- 2020 годах. Были проанализированы схемы медикаментозного лечения (РМЖ) на основе клинического протокола. По состоянию на 01.12.2019 года. Для лечения РМЖ в Украине было зарегистрировано 184 ЛС, а на 01.12.2020. - уже 194. В 2020 году большую часть среди ЛС принадлежит группе антинеопластических и иммуномодулирующих средств - 82,0\%, а в группе средств, влияющие на опорно-двигательный аппарат - 18,0\%. По состоянию на 01.12.2020 года ЛС представлены 43 фирмами-производителями, из них 18,6\% - украинские, 81,4\% - иностранные. Среди украинских фирм первенство принадлежит «Фармекс групп» $(4,1 \%)$, «Тева-Украина» $(3,1 \%)$ и «Фармак» $(2,6 \%)$. Наибольшее количество среди иностранных поставщиков занимают Великобритания - 26,3\%, Швейцария и Индия по 11,9\%. Значительное количество ЛС из Великобритании поставляет фирма-производитель «Мистрал Кэпитал Менеджмент Лимитед» - 9,3\%, из Швейцарии - «Ф. Хоформанн-Ля Рош Лтд» - 8,2\% и Индии - «Нижнее Лабз Лимитед »4,6\%. В то время в 5 фармакотерапевтических группах (L01AA01, L01BA01, L01CA04, L01XC07, M05BA03) не представлено ни одного препарата от украинского производителя. Анализ ассортимента ЛС для лечения РМЖ за лекарственными формами в 2020 году показал, что основная их часть $(35,6 \%)$ представлена концентратом для приготовления раствора для инфузий, $21,6 \%$ - таблетками и 20,6\% - лиофилизат для приготовления раствора для инфузий. Другие лекарственные формы, такие как порошок для приготовления раствора для инъекций, раствор для инъекций, раствор для инфузий, порошок для приготовления раствора для инфузий и порошок лиофилизированный для приготовления раствора для инфузий, составляют в совокупности $22,2 \%$ от общего ассортимента группы ЛС, изучаемого на рынке Украины.

Ключевые слова: новообразования груди, противоопухолевые средства, иммуномодуляторы, новообразования груди, опорно-двигательного аппарата. 